\title{
Geochemistry and Petrogenesis of Diabase Dykes in the Northern Part of EDC, Karnataka, India: Implication for Sulfide Metal Exploration
}

\author{
Bhimasandra Chikkanna Prabhakar \\ Department of Geology, Bangalore University, Bangalore, India \\ Email: bcprabhakar@rediffmail.com
}

How to cite this paper: Prabhakar, B.C. (2018) Geochemistry and Petrogenesis of Diabase Dykes in the Northern Part of EDC, Karnataka, India: Implication for Sulfide Metal Exploration. Open Journal of Geology, 8, 87-103.

https://doi.org/10.4236/ojg.2018.82006

Received: November 6, 2017

Accepted: February 2, 2018

Published: February 5, 2018

Copyright $\odot 2018$ by author and Scientific Research Publishing Inc. This work is licensed under the Creative Commons Attribution International License (CC BY 4.0).

http://creativecommons.org/licenses/by/4.0/

(c) (i) Open Access

\begin{abstract}
Northern part of Eastern Dharwar Craton (EDC) in Karnataka is essentially a granitoid country, frequently intruded by diabase dykes of varied dimensions. Compositionally, majority of them are constituted by pyroxene and plagioclase and less frequently they are olivine-bearing types. One of the major dykes near Thinthini is intensely altered and contains sulfide mineralization brought out by episodic hydrothermal process. Geochemically they are slightly on the higher side of silica content, except the olivine bearing dykes. Their sulfur endowment is also higher. Various discrimination diagrams suggest that they are broadly tholeiitic in composition formed from the less differentiated magma derived from mantle at relatively greater depth and intruded into the granitic rocks which in turn were formed in a subduction setting. The structural deformation prior to and post dating dyke intrusion as deciphered from detailed field studies, alteration of country rocks and hydrothermal activity in the area provide a good background to explore sulfide and other associated metals and also to understand the likely extension of the known mineralized zones.
\end{abstract}

\section{Keywords}

Diabase Dykes, EDC, Sulfide Mineralization, Thinthini, Mineral

Exploration

\section{Introduction}

Dharwar Craton in India is chiefly made up of granites and greenstones. Based on broader lithology, structural features and geodynamic setting this craton is divided into western and eastern Dharwar Cratons (WDC and EDC) [1] [2]. Diabase dykes are omnipresent in the entire craton. However, they occur as huge 
swarms in the southern part of the craton [3], and are relatively lesser in occurrence, yet make a significant presence in the northern parts of the craton as well. They are frequently seen intruding the granitic rocks in northern part of EDC, especially around Thinthini (Figure 1). There are both mineralized and unmineralised dykes. Their study is important from the point of understanding crustal evolution, geodynamic setting and magma evolution, besides their metallogenic significance. However, very few studies have been carried out for this area, especially on the diabase dykes and mineralization episode [4]. In the present study, a few representative dykes occurring around Thinthini, north of Hutti schist belt, have been studied for their petrogenesis and mineralization perspectives. This study is hoped to bridge the gap in understanding the episodic magmatic activity and associated mineralization events in the northern part of eastern EDC.

During the present investigation, detailed mapping and sampling have been carried out in the study area. The representative samples were subjected for petrographic and geochemical studies and the results of these studies along with the results of field investigation have been interpreted to understand the petrogenetic and mineralization aspects of the diabase dykes.

\section{Field Setting}

In the study area, i.e. the granitoid terrain north of Hutti schist belt, dykes with different spatial extent are commonly observed. They vary from about $2 \mathrm{~m}$ to a maximum of $20 \mathrm{~m}$ in width and they run (trending) for 2 to $20 \mathrm{~km}$. Almost all the dykes are vertical, with a straight and occasionally curvilinear course. Their outcrops are generally seen in the form of boulders and occasionally they show well established contacts with the country rocks (Figure 2). Although the diabases are younger than other major lithologies (gneisses and granites), they do not contain xenoliths of the older rocks, and there are no signs of any dismemberment and digestion of the country rocks. Majority of the dykes recorded showed major trend along E-W direction and only a few showed different trends. Based on mineralogy and texture they have been grouped into two varieties, viz. 1) Normal diabase; and 2) Olivine diabase.

\subsection{Normal Diabase}

Normal diabases are dominant among the two varieties. They are greyish green coloured, medium to coarse grained, with laths of plagioclase studded in dark mass of clinopyroxene. One of the diabases of this variety which is confined to a fracture/shear zone near Thinthini hosts sulfide mineralisation. The mineral assemblage and texture of this diabase indicate that it has been intensely altered. The significant mineralogical changes in this diabase are the intense chloritisation of the primary minerals. In the intensely sheared portions, it resembles chlorite schist with smooth and fragile appearance. The less altered portions still show granular and compact nature. Mineralogically it is made up of chloritised 


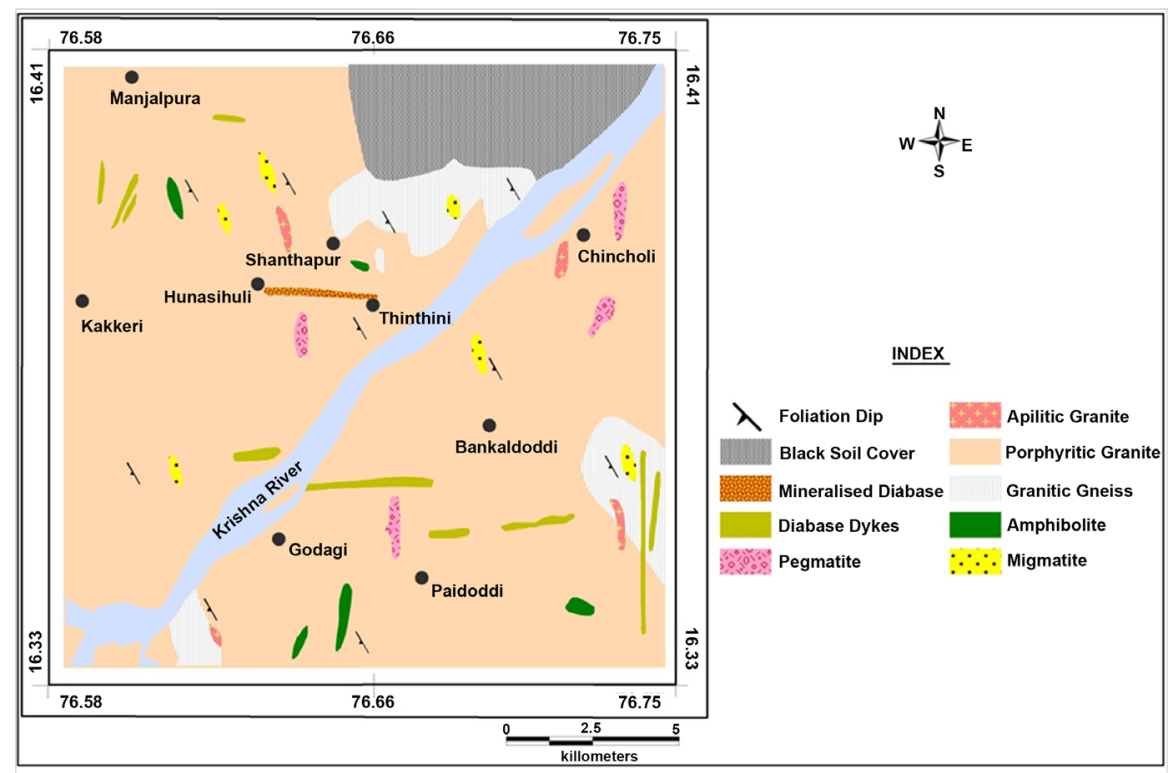

Figure 1. Geological map of Thinthini area in the northern part of EDC.

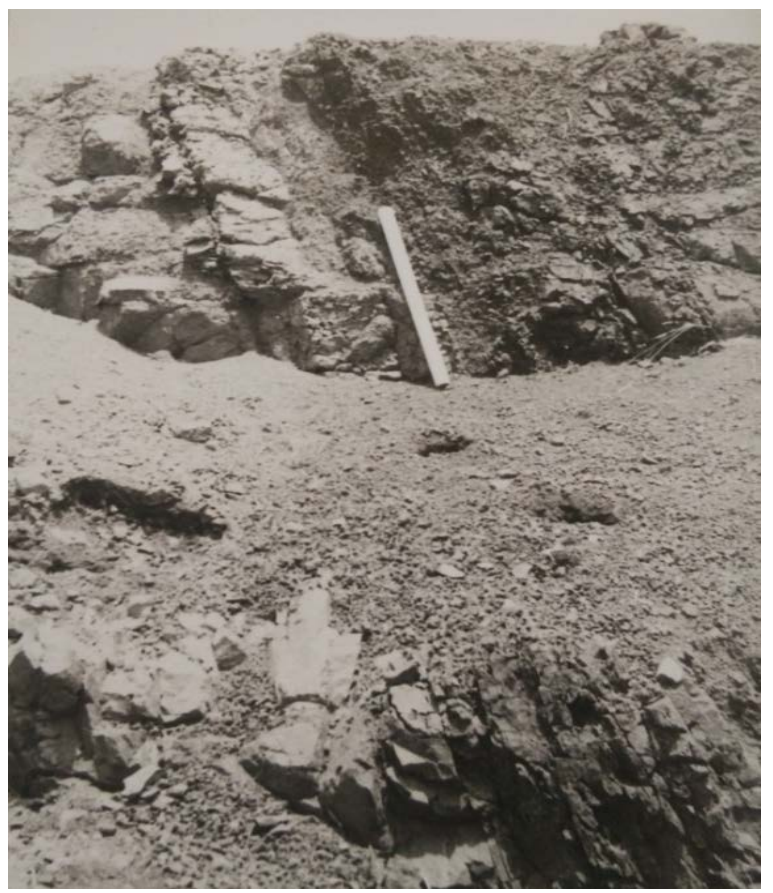

Figure 2. Sharp contact between the altered diabase dyke (to the right side of the rolled map kept for scale) and granite near Thinthini.

clinopyroxene, sausseritised plagioclase and micropegmatite with disseminated opaque minerals like pyrite, chalcopyrite and magnetite-ilmenite. Gradual variation in grain size from coarse to fine can be traced from centre of the diabase to periphery. At the contact it shows the effect of chilling and pilotaxitic texture. In the less deformed portions, it still preserves ophitic texture where tabular and lath shaped plagioclase is partially enclosed by altered augite grains (Figure 3(a)). 


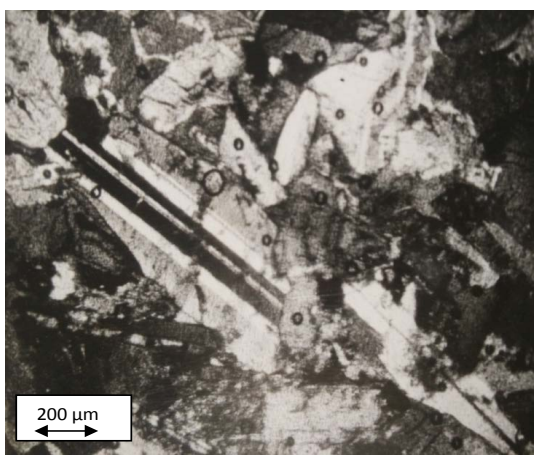

(a)

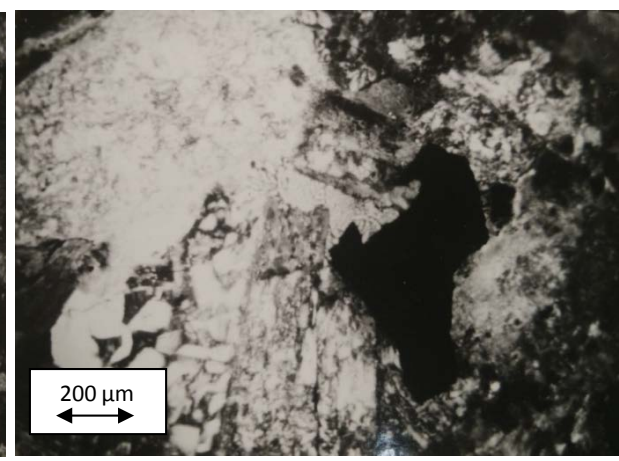

(b)

Figure 3. (a) Laths of plagioclase enclosed by altered augite grains in normal diabase; (b) Microphotograph showing development of micropegmatite within the altered plagioclase laths in the mineralized diabase.

Chlorite occurs as fresh green coloured patches. Micropegmatite is seen as small pegs within the interstices of plagioclase (Figure 3(b)). Numerous veins and stringers of epidote, calcite and quartz permeate throughout the rock. The intensely altered and veined portions of the diabase host richer sulfide mineralization.

The diabase dykes other than the mineralised one are generally medium to coarse grained, fresh and less altered. They consist of augite and plagioclase as chief minerals. They exhibit ophitic to sub-ophitic texture. Chlorite and micropegmatite are occasionally seen as deuteric alteration products. Magnetite is the chief accessory mineral.

\subsection{Olivine Diabase}

Olivine diabases are limited in occurrence. They are fine to medium grained and show dark grey colour in hand specimen. In thin sections they show the presence of augite, plagioclase and olivine as chief mineral constituents. They exhibit porphyritic texture. Phenocrysts of olivine and augite are seen in the fine grained groundmass of olivine, augite and plagioclase. Olivine occurs as anhedral and rounded grains with thick iron rich borders (Figure 4). Sometimes coarse grained aggregates of olivine are also noticed. Discrete grains of magnetite commonly occur as accessory mineral. The modal compositions of different diabases are given Table 1.

\section{Mineralogy}

Plagioclase: It is a common constituent in all the diabases. In normal unaltered diabases plagioclase is fresh and well twinned. It occurs as medium grained lath shaped and equidimensional grains. In olivine diabase it occurs as slender elongated needles with two individuals in a needle. In the intensely altered sulfide bearing diabase, plagioclase is commonly sausseritised. Under crossed nicolsit shows incipient colour development. Here plagioclase grains show brownish grey colour and the effect of clouding. Divergent views have been expressed on 


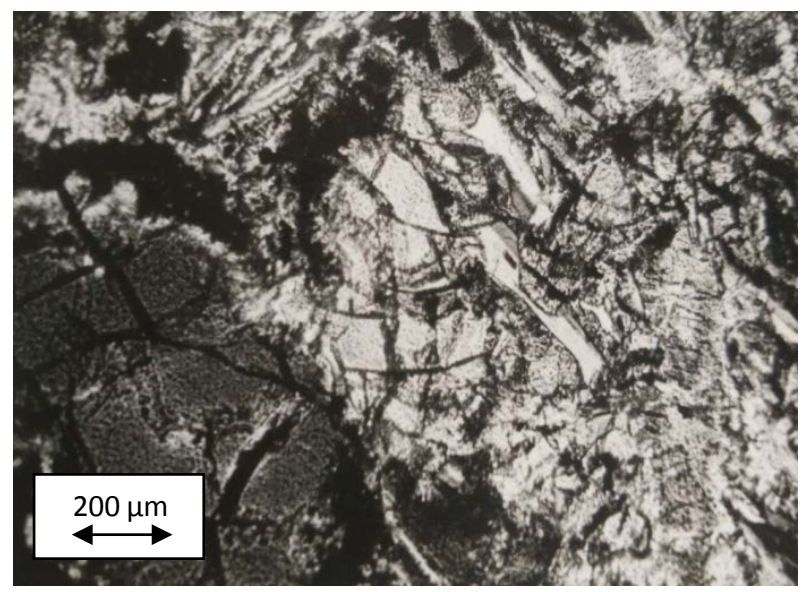

Figure 4. Fractured and thickly rimmed olivine phenocryst in the ground mass of slender plagioclase and granular to tabular augite, in olivine diabase.

Table 1. Modal composition (\%) of diabase dykes in the study area.

\begin{tabular}{cccccc}
\hline Minerals & AV.M & $\mathbf{1 6}$ & 30 & 37 & 56 \\
\hline Quartz & 1.124 & 2.15 & 4.8 & 1.06 & - \\
Plagioclase & 28.65 & 50.23 & 53.37 & 46.5 & 38.12 \\
Clinopyroxene & 2.598 & 35.97 & 32.55 & 31.89 & 48.56 \\
Olivine & - & - & - & - & 7.83 \\
Hornblende & - & 8.99 & 3.38 & - & - \\
Chlorite & 29.436 & - & - & 12.14 & - \\
Micropegmatite & 28.132 & - & - & - & - \\
Opaques & 10.09 & 2.64 & 5.98 & 8.5 & 5.48 \\
Total & 100.03 & 99.98 & 100.08 & 100.09 & 99.99 \\
\hline
\end{tabular}

Sample description: AV. M: Average modal composition of 5 samples of altered/mineralised diabase near Thinthini; 16: Normal diabase, a km north of Kakkeri; 30: Normal diabase about $3 \mathrm{~km}$ west of Lingadahalli; 37: Normal diabase about a $\mathrm{km} \mathrm{N} 55^{\circ} \mathrm{W}$ of Bankaldoddi; 56: Olivine diabase $2 \mathrm{~km} \mathrm{NW}$ of Kakkeri.

the origin of clouding in plagioclase [5] [6]. Based on the study of dolerite dykes of the charnockitic and non-charnockitic regions of Karnataka, Pichamuthu [7] concluded that only plagioclase occurring in the dykes of charnockitic regions are clouded and he accounted this phenomena to the intense thermal metamorphism of the dolerites by the younger charnockitic intrusives. Niadu [8] in his work on plagioclase of Pallavaram noritic dykes found no evidence of thermal metamorphism and concluded that cloudiness in the dykes is produced by diffusion of iron ions in the deuteric stage of the evolution of these dykes.

The clouding of the plagioclase in the sulfide bearing diabase of the study area, thus, can be attributed to the intense deuteric alteration during the later stages of diabase emplacement, probably coinciding with the mineralising event. The thermal metamorphic process cannot be accounted because these dykes post-date all the metamorphic events in the study area. 
Augite: It occurs as fine to medium grained subhedral grains. Cleavages are poorly developed and it is non-pleochroic. Both twinned and untwined grains are present and twinning is simple. It invariably alters to chlorite in mineralised diabase and occasionally to hornblende in other diabases.

Olivine: It is fine to medium grained, anhedral and rounded with commonly seen irregular fractures. Majority of the grains are fresh. Sometimes it occurs as segregates of coarse grains. The borders of the grains are invariably rimmed by iron oxide.

Micropegmatite: The intergrowth-like structure between quartz and plagioclase to form micropegmatite is commonly seen in the altered/mineralised diabase. Triangular to rectangular plates and pegs of quartz are noticed within the interstices of plagioclase and they extinguish simultaneously over some area. It is noticed that the twinned plagioclase enclosing the pegs and plates of quartz is optically continuous over large area, thereby indicating that the twinned laths of plagioclase were formed earlier but were later replaced by quartz. The size and shape of micropegmatite intergrowth varies from section to section and even within a single section. The triangular and rectangular plates of quartz may be just one, two or numerous, giving rise to a cauliflower like intergrowth with the size ranging from microscopic to sub-microscopic.

Different views like solid solution, deuteric action of silica rich residuals, assimilation of psammatic sediments, have been advocated for the origin of the micropegmatite [9]. The altered diabase is free from psammatic xenoliths or those of the country rock through which it is intruded. It appears therefore, that the development of micropegmatite is due to deuteric action of silica rich residuum which has replaced the laths of plagioclase along their margins. With further replacement, the plagioclase laths have lost their outlines having been replaced by pegs and vermicules of quartz. The final stage of replacement is represented by a large area of micropegmatite with relic plagioclase laths in between.

Chlorite: It has been largely derived from the alteration of primary minerals in the altered diabase. It occurs as fine to medium grained scaly leaves, patches and streaks. In thin section it is clear and fresh and show green colour. It is pleochoroic with $\alpha$ = green, $\beta$ = pale yellow, $\sqrt{ }=$ pale yellow. Under crossed nicols it remains nearly isotropic and sometimes shows anomalous blue interference colour.

Accessory (opaque) minerals: Iron oxide is a common accessory in both the varieties of diabase. In sulphide bearing diabase, magnetite associated with ilmenite is frequently seen. In this diabase sulfide minerals like pyrite and chalcopyrite are disseminated as discrete grains. The mode of these disseminated minerals does not exceed $10 \%$ (excluding vein portions).

Apart from the above mentioned minerals, quartz and calcite are invariably seen in the sulfide bearing diabase and these minerals occur in the form of veins of varying length and breadth. These veins are the main carriers of sulfide ore minerals. Growth of calcite is conspicuous in most veins (Figure 5(a)). In hand 


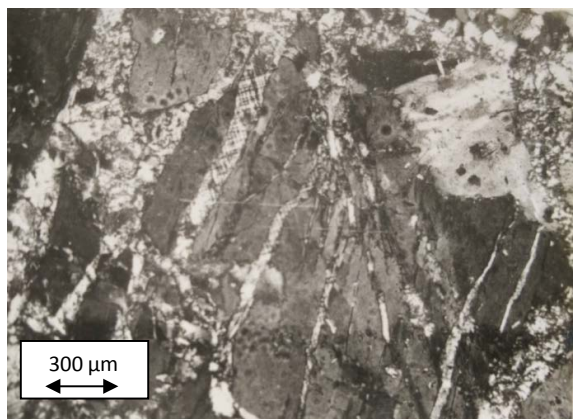

(a)

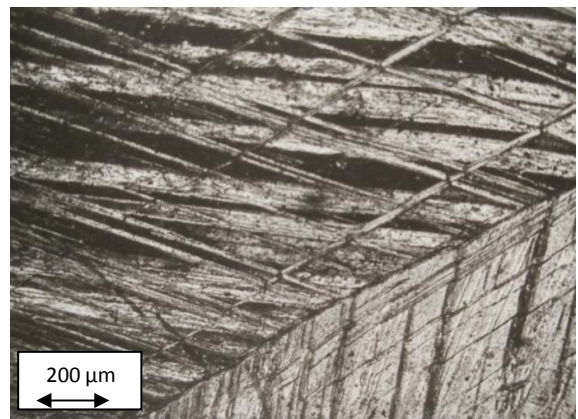

(b)

Figure 5. (a) Microphotograph showing calcite veins and veinlets along with quartz veins in altered diabase; (b) Rhombohedral cleavages and twin lamellae developed in fracture filling calcite veins within the altered and mineralized diabase.

specimen it shows white and pale pink colours. Rhombohedral cleavages and twin lamellae are beautifully developed in them (Figure 5(b)). Bright purple coloured fluorite commonly occurs as coarse grained cubic crystals in close association with quartz veins.

\section{Geochemistry}

Diabase dykes constitute a very important suit of rocks not only for the diversity in their mineral composition, but also for their economic importance. Different generations of dykes in Dharwar craton have been established by workers like Divakara Rao et al. [10], Satyanarayana et al. [11], Naqvi et al. [12] and Devaraju [3] largely by studying the geochemistry of these intrusives and also the nature of metamorphism they have suffered. Here, an attempt is made to establish the affinity of the diabase dykes of the study area to possible geodynamic setting and magma process based on their geochemical characteristics.

Five representative samples of diabase dykes from the study area have been analysed for major and three samples for trace elements. Major elements were analysed by XRF and trace elements by AAS methods. The detection limit for $\mathrm{Pb}$ and $\mathrm{Nb}$ was $10 \mathrm{ppm}$ and for all other elements it was $5 \mathrm{ppm}$. Out of the five major element analyses (Table 2), four represented the normal diabases and one olivine diabase. For altered and mineralised diabase five analyses have been carried out and the values averaged. Trace element contents in the mineralised diabase (average of 3 values) and in the other two diabases are also listed in Table 3.

From the analyses, it is deciphered that the diabases of the study area show somewhat higher $\mathrm{SiO}_{2}$ content, but show lesser variation. In normal diabases it ranges from $52.0 \%$ to $56.55 \%$ where the altered diabase accounts for the higher silica content. The olivine diabase has $50.27 \%$ of $\mathrm{SiO}_{2}$. Less variation is noticed in $\mathrm{Al}_{2} \mathrm{O}_{3}$ proportion, which varies from $12.63 \%$ to $14.14 \%$, the lowest being in olivine diabase. Very little variation is observed in $\mathrm{MgO}$ content of the different diabases. It varies from $4.58 \%$ to $9.46 \%$, the highest value being in olivine diabase and the lowest in the altered diabase. Not much variation is recorded in 
Table 2. Major element analyses of diabases of study area.

\begin{tabular}{ccccccccc}
\hline Constituents & $\mathrm{AV} . \mathrm{M}$ & $\mathbf{1 6}$ & $\mathbf{3 0}$ & $\mathbf{3 7}$ & $\mathbf{5 6}$ & $\mathrm{AM}$ & $\mathrm{AO}$ & $\mathrm{AC}$ \\
\hline $\mathrm{SiO}_{2}$ & 56.55 & 53.5 & 53.535 & 52 & 50.271 & 51.4 & 49.61 & 49.9 \\
$\mathrm{Al}_{2} \mathrm{O}_{3}$ & 12.878 & 13.47 & 12.86 & 14.16 & 12.63 & 14.85 & 16.01 & 16.2 \\
$\mathrm{Fe}_{2} \mathrm{O}_{3}$ & 2.374 & 2.665 & 3.841 & 3.672 & 2.56 & 1.26 & - & 3 \\
$\mathrm{FeO}$ & 10.225 & 11.05 & 9.56 & 8.835 & 9.53 & 8.55 & $11.49^{*}$ & 7.8 \\
$\mathrm{MgO}$ & 4.588 & 5.875 & 6.99 & 6.62 & 9.464 & 6.36 & 7.84 & 6.3 \\
$\mathrm{CaO}$ & 7.14 & 8.747 & 8.342 & 8.07 & 11.02 & 12.16 & 11.32 & 9.8 \\
$\mathrm{Na}_{2} \mathrm{O}$ & 2.43 & 1.876 & 1.59 & 2.278 & 1.85 & 2.19 & 2.76 & 2.8 \\
$\mathrm{~K}_{2} \mathrm{O}$ & 0.9 & 0.6 & 1 & 0.84 & 0.71 & 0.51 & 0.22 & 1.1 \\
$\mathrm{TiO}_{2}$ & 1.228 & 0.955 & 0.861 & 1.888 & 0.85 & 0.69 & 1.43 & 1.6 \\
$\mathrm{P}_{2} \mathrm{O}_{5}$ & 0.284 & 0.345 & 0.28 & 0.437 & 0.361 & 0.14 & - & 0.3 \\
$\mathrm{MnO}^{2}$ & 0.18 & 0.136 & 0.17 & 0.223 & 0.05 & 0.53 & 0.18 & 0.17 \\
$\mathrm{H}_{2} \mathrm{O}$ & 0.39 & 0.72 & 0.718 & 0.65 & 0.72 & - & - & 1 \\
$\mathrm{~S}$ & 0.433 & 0.161 & 0.161 & 0.112 & 0.02 & - & - & - \\
$\mathrm{Total}$ & 99.6 & 100.1 & 100.05 & 99.785 & 100.03 & 98.64 & 100.86 & 99.97 \\
\hline
\end{tabular}

${ }^{*}$ Total iron as FeO; Sample description: AV.H, 16, 30, 37, 56 as in Table 1; AM: Average compositions of tholeiites of Chitradurga Schist Belt [17]; AO: Average oceanic tholeiite [18]; AC: Average continental tholeiite [19].

Table 3. Trace element analyses of diabases of study area and comparison with other diabases.

\begin{tabular}{ccccccc}
\hline Constituent & AV.M & $\mathbf{1 6}$ & $\mathbf{5 6}$ & AK & AQ & AO \\
\hline $\mathrm{Cu}$ & 560 & 225 & 210 & & 135 & 77 \\
$\mathrm{~Pb}$ & $<10$ & $<10$ & $<10$ & $<10$ & $<10$ & $<10$ \\
$\mathrm{Ni}$ & 88 & 75 & 80 & 70 & 76 & 97 \\
$\mathrm{Co}$ & 60 & 45 & 55 & 30 & 38 & 32 \\
$\mathrm{Mo}$ & 5 & 5 & 5 & - & - & - \\
$\mathrm{Zr}$ & 76 & 80 & 60 & 88 & 111 & 95 \\
$\mathrm{Cr}$ & 128 & 140 & 160 & 293 & 152 & 297 \\
$\mathrm{~V}$ & 220 & 230 & 250 & 225 & 266 & 298 \\
$\mathrm{Ga}$ & 18 & 10 & 10 & 24 & 21 & 17 \\
$\mathrm{Y}$ & 15 & 20 & 20 & 22 & 30 & 45 \\
$\mathrm{Nb}$ & $<10$ & $<10$ & $<10$ & $<10$ & $<10$ & $<10$
\end{tabular}

Sample description: AV.M, 16 and 56 as in Table 1; AK: Average Karoo dolerite [20]; AQ: Average quartz normative tholeiite [21]; AO: Average oceanic tholeiite basalt [22].

both $\mathrm{FeO}$ and $\mathrm{Fe}_{2} \mathrm{O}_{3}$ contents. $\mathrm{CaO}$ content ranges from $7.1 \%$ to $11.02 \% . \mathrm{Na}_{2} \mathrm{O}$ and $\mathrm{K}_{2} \mathrm{O}$ have marginal variation. Appreciable variation is noticed in the sulfur distribution. It varies from $0.02 \%$ to $0.433 \%$, the highest value being in altered and mineralised diabase. 
The distribution of trace elements in the altered and unaltered diabases indicates that contents of these elements except for $\mathrm{Cu}$ are nearly same. The $\mathrm{Cu}$ content in the altered diabase is much higher (560 ppm) than the normal values. In the unaltered diabase, $\mathrm{Cu}$ content varies from 210 - $255 \mathrm{ppm}$.

Vanadium varies from 220 to $250 \mathrm{ppm}$. It shows positive correlation with $\mathrm{Fe}^{3+}$ and it is evident that it has followed $\mathrm{Fe}^{3+}$ in the dykes. Co varies from 45 to 60 ppm and Ni from 75 to $88 \mathrm{ppm}$. Y varies from 12 to $20 \mathrm{ppm}$ and it shows positive correlation with $\mathrm{Ca}$. Zr varies from 60 to $80 \mathrm{ppm}$ and $\mathrm{Cr}$ from 128 to 160 ppm, the highest value being in olivine diabase. Cr shows positive correlation with $\mathrm{Fe}^{3+}$ content and it is evident that it has been accommodated in magnetite structure. Ba and Sr contents vary slightly.

\section{Petrogenesis}

To know the magmatic affinities and differentiation trend of the diabases of study area certain discriminating geochemical diagrams have been drawn.

In the alkali against silica diagram of Macdonald and Kastura [13], all the diabases fall in the field of tholeiite (Figure 6). The tholeiite nature of diabases is also evident from $\left(\mathrm{Na}_{2} \mathrm{O}+\mathrm{K}_{2} \mathrm{O}\right)-\mathrm{FeO}(\mathrm{T})-\mathrm{MgO}$ plot (Figure 7). In this diagram all the diabases form differentiation sequences similar to Bighorn dolerite trend [14], Precambrian Beartooth metadolerites [15] and Tasmanian continental tholeiites [16], all of which follow the Skaergaard trend. The altered diabase shows slightly more iron enrichment trend than the other diabases.

Like the Bighorn, Beartooth and Tasmanian dolerites the trends of diabases of study area do not exhibit the extreme concentration of iron of the Skaergaard trend. The olivine diabase plots on the alkali-deficient side of the Tasmanian trend. The tholeiite nature of the diabases of the study area is further evident in $\mathrm{Zr}$ (ppm) $-\mathrm{TiO}_{2} \%$ diagram (Figure 8) of Floyd and Winchester [26].

Plots of the analyses on a $\mathrm{TiO}_{2}-\mathrm{K}_{2} \mathrm{O}-\mathrm{P}_{2} \mathrm{O}_{5}$ ternary diagram (Figure 9) permit discrimination between oceanic and continental basalt types according to Pearce

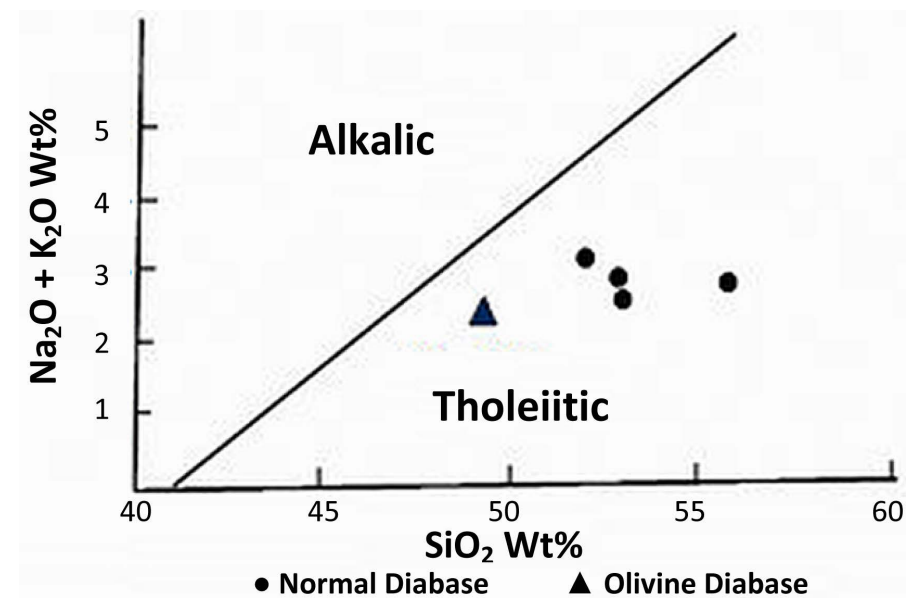

Figure 6. Alkali-Silica diagram for diabases of study area (after Macdonald and Kastura, 1964) [13]. 


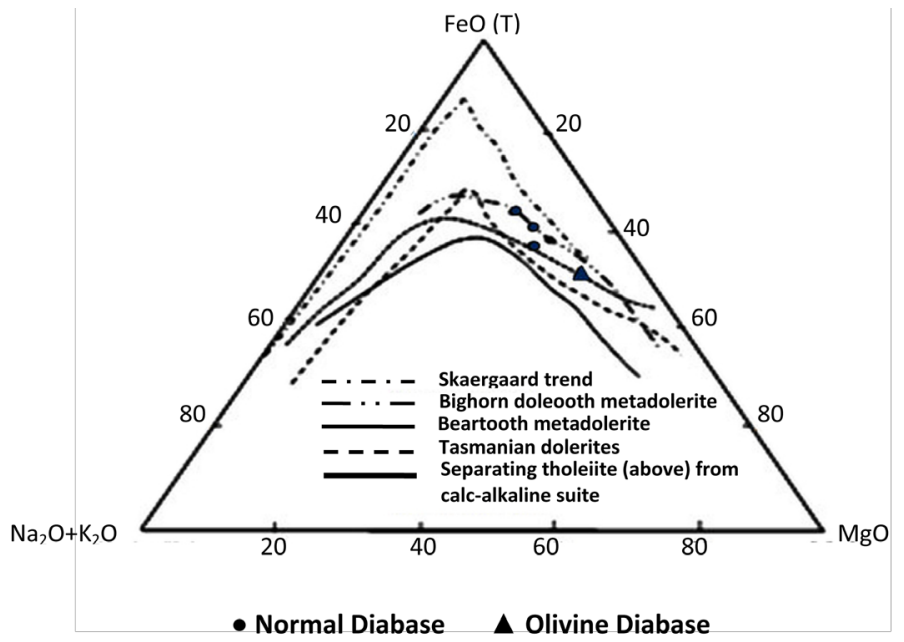

Figure 7. A-F-M diagram for diabases of study area.

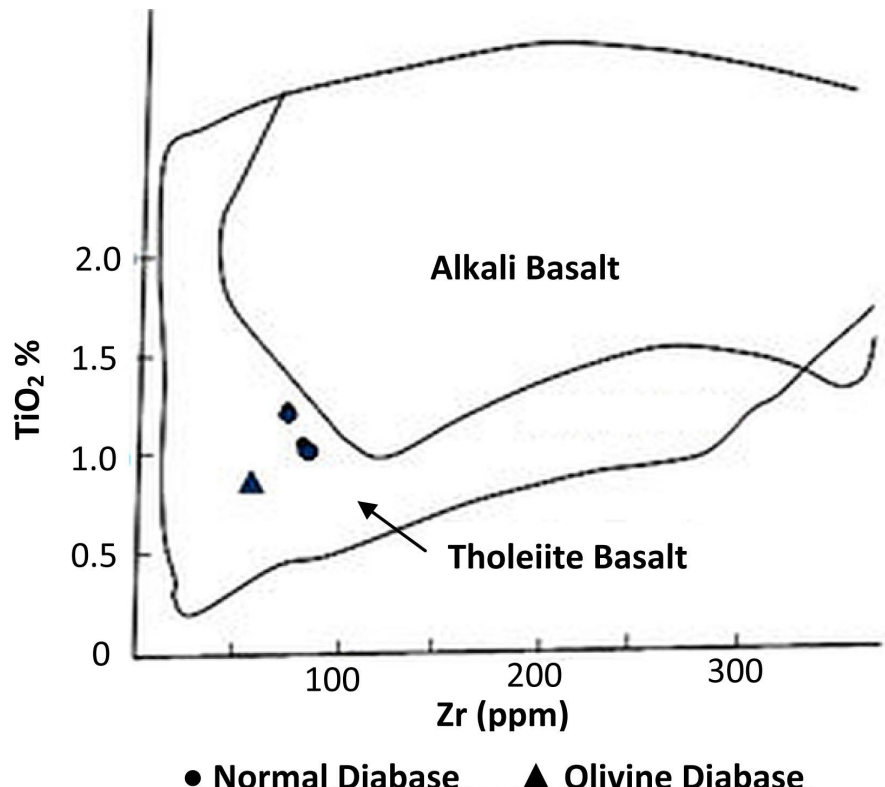

Figure 8. $\mathrm{Zr}-\mathrm{TiO}_{2}$ plot for diabases of study area (after Floyd and Winchester, 1975) [26].

et al. [27]. All the diabases of study area fall on the continental basalt side of the diagram. In the differentiation diagram (Figure 10), where different oxide percentages are plotted against differentiation index $\left(\mathrm{DI}=100\left(\mathrm{FeO}+\mathrm{Fe}_{2} \mathrm{O}_{3}\right) / \mathrm{FeO}+\right.$ $\mathrm{Fe}_{2} \mathrm{O}_{3}+\mathrm{MgO}$ ), the diabase of study area show moderate differentiation trend.

The diabases of study area do not differ in gross chemistry, except for slightly higher content of silica in altered diabase, than the other diabases. The average major element proportions of diabases closely resemble the average continental tholeiite. Lithologically similar mafic dykes from the Beartooth mountains [15], and Precambrian Wyoming diabases [24], have average compositions, especially $\mathrm{K}_{2} \mathrm{O}(0.95 \% \& 0.85 \%)$, more comparable with average continental tholeiites $\left(\mathrm{K}_{2} \mathrm{O}\right.$ $1.1 \%)$. The $\mathrm{K}_{2} \mathrm{O}$ content of diabases of study area are intermediate between low 


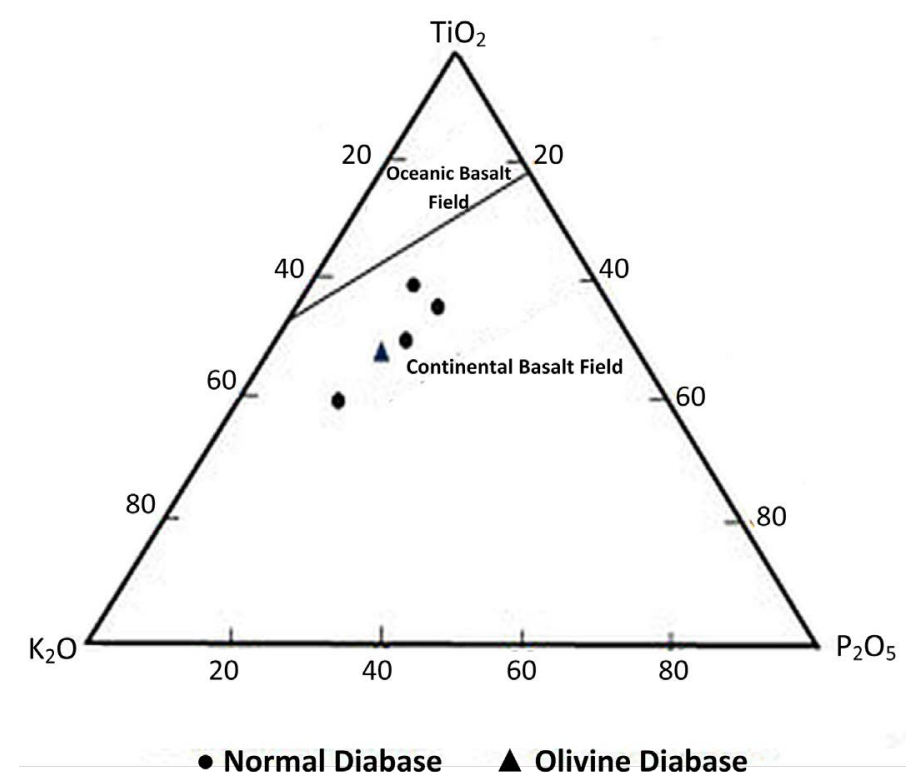

Figure 9. $\mathrm{TiO}_{2}-\mathrm{K}_{2} \mathrm{O}-\mathrm{P}_{2} \mathrm{O}_{5}$ diagram for diabases of the study area (After Pearce et al., 1975) [27].

$\mathrm{K}_{2} \mathrm{O}$ oceanic tholeiite and high $\mathrm{K}_{2} \mathrm{O}$ continental tholeiite, but they are more close to the continental tholeiite values. The Precambrian mafic dykes in the Indian shield as studied by Naqvi and Hussain [17] and the dyke swarms in Canadian Shield as studied by Fahrig and Eade [28], which are younger than Archaean metabasalts, nearly resemble the $\mathrm{K}_{2} \mathrm{O}$ content of continental tholeiite.

The average concentrations of ferromagnesian trace elements in diabases of study area resemble that of the average Karoo continental tholeiite [20], and average quartz normative tholeiite [21], (Table 3), except for higher concentrations of $\mathrm{Cu}$ and slightly higher concentrations of $\mathrm{Co}$ and $\mathrm{Ni}$ and perhaps lower concentrations of $\mathrm{V}$ and $\mathrm{Zr}$. These average concentrations suggest that the diabases of study area are somewhat less fractionated. Comparison of average concentrations of $\mathrm{K}$, the $\mathrm{K}$-related elements viz. Sr and $\mathrm{Ba}$ and their ratios in diabases in the study area again emphasize the similarities in these rock series (Table 4). The value of $\mathrm{K}$ and $\mathrm{Ba}$ are nearly identical to the continental tholeiite [23], (Table 4) and Precambrian diabases [24], (Table 4), except for Sr which is slightly higher.

Naqvi and Hussain [17] have taken the $\mathrm{K}_{2} \mathrm{O}$ content in different types of tholeiites as a criterion to know the thickness and composition of the crust into which these tholeiites are emplaced. According to them the continental tholeiites were emplaced in a thicker and more differentiated crust and by contamination acquired more $\mathrm{K}_{2} \mathrm{O}$. In contrast, Jamieson and Clark [29], suggest that $\mathrm{K}_{2} \mathrm{O}$ enrichment in continental tholeiites depends on the degree of partial melting of the mantle during magma generation, crystal-liquid fractionation, mantle-wall reaction, and mantle inhomogeneity, rather than crustal contamination.

The $\mathrm{K}_{2} \mathrm{O}$ concentration of diabases of study area (average of normal diabases $0.83 \%$, olivine diabase $0.71 \%$ ), which are characteristic of continental tholeiite, 


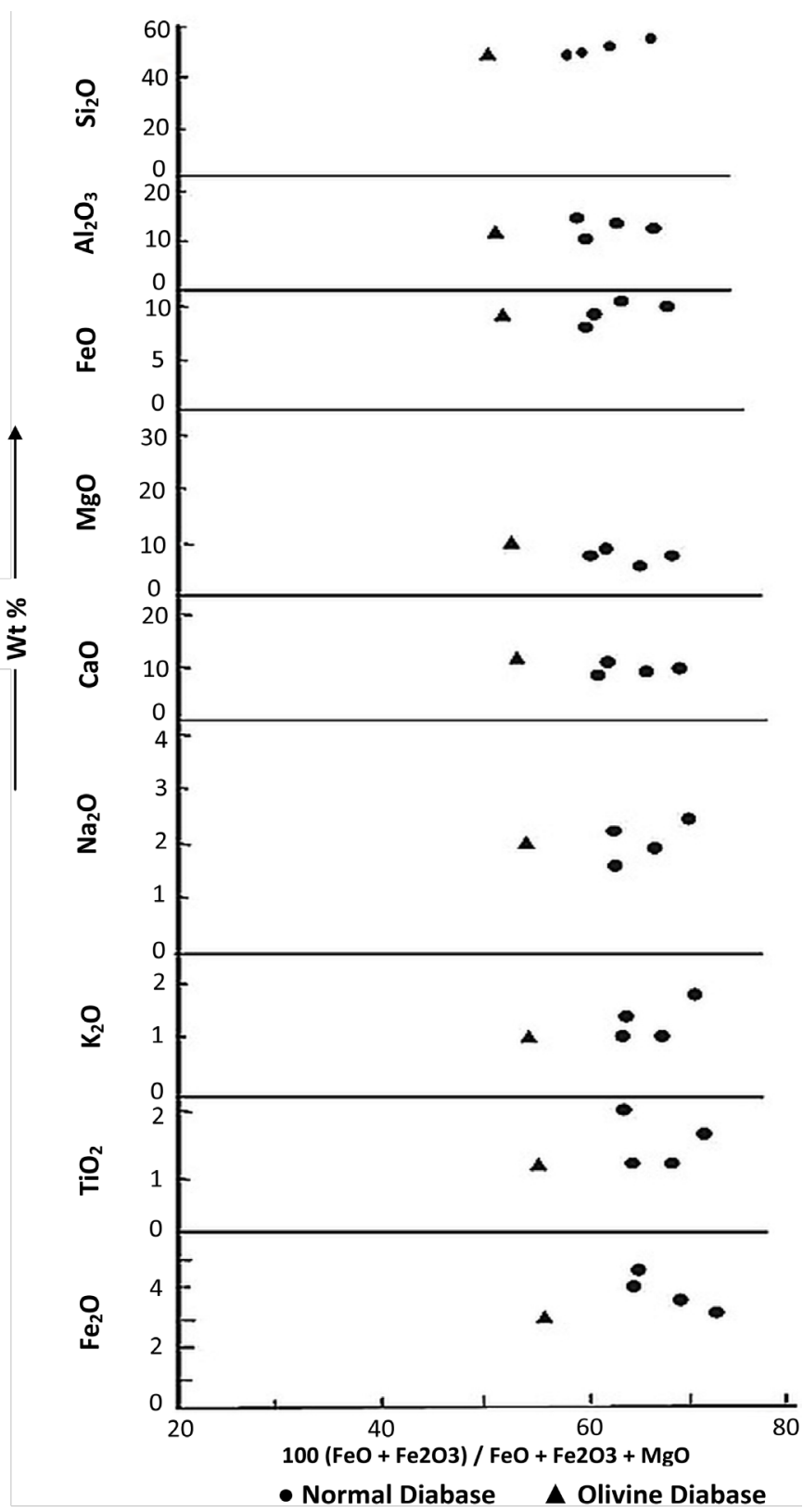

Figure 10. Differentiation index diagram for diabases of the study area.

therefore, indicate their emplacement probably in a thicker crust. Opinions differ as regards the mode of differentiation of the tholeiitic quartz diabase association [30]. Experimental studies suggest that the composition of the magmas produced by the partial melting of the peridotites would become more silica deficient with the increase of pressure and that the silica saturated tholeiite magma cannot be formed below $60 \mathrm{~km}$ [31]. According to Kuno [32], the different basaltic magmas are produced independently at different depths. Yoder and Tilley [33] are of the opinion that melting of mantle at some depth results in olivine tholeiite and tholeiite which on fractionation give rise to alkali olivine basalt and saturated tholeiite. 
Table 4. Concentrations of $\mathrm{K}$ and K-related elements.

\begin{tabular}{ccccccc}
\hline Elements & AV.M & $\mathbf{1 6}$ & $\mathbf{3 0}$ & AT & AW & AM \\
\hline $\mathrm{K}$ & 7470 & 4980 & 8301 & 7600 & 7900 & 2359 \\
$\mathrm{Sr}$ & 200 & 150 & 200 & 123 & 186 & 153 \\
$\mathrm{Ba}$ & 298 & 300 & 350 & 352 & 320 & 98 \\
$\mathrm{Sr} / \mathrm{Ba}$ & 0.67 & 0.5 & 0.57 & 0.35 & 0.58 & 1.56 \\
$\mathrm{~K} / \mathrm{Ba}$ & 25.06 & 16.6 & 23.71 & 22 & 25 & 24 \\
$\mathrm{~K} / \mathrm{Sr}$ & 37.35 & 32.2 & 41.5 & 62 & 42 & 15.4 \\
\hline
\end{tabular}

Sample description: AV.M, 16, 30 as in Table 1; AT: Antarctic and Tasmanian dolerites [23]; AW: Wyoming Precambrian diabases [24]; AM: Average Archean metabasalt [25].

Based on these grounds, and crystallization/differentiation trend as visualised through various petrochemical diagrams, it can be concluded that the abundant quartz diabases were available in greater bulk after the differentiation of the parent tholeiite magma and the depth of parent magma formation was probably greater and the silica saturated fractionates were derived at a depth lesser than 60 $\mathrm{km}$, since silica saturated tholeiite cannot exist below that depth [31]. Subsequently, they intruded as mafic sweats into the granitoid rocks which in turn formed in a subducting geodynamic setting [34].

The overall similarity in chemistry and the common regional trend of majority of the diabase dykes indicate their origin during a single intrusive activity, the source being a common parental magma. The observed shearing in altered and mineralized diabase has been caused during the later deformational activity during which period the diabase along with adjacent country rocks was fractured. None of the other dykes other then the altered diabase, show any significant deformational effects.

\section{Implications for Mineral Exploration}

Tholeiitic mafic bodies, by and large, are the hosts for most sulfide ore bodies in the greenstone belts of Dharwar craton (eg., Ramakrishnan [35], Sarma et al. [36]) and elsewhere (e.g. [37], Nielsen and Brooks [38]). $\mathrm{Cu}, \mathrm{Ag}$, Au etc are mostly confined to these belts, and dykes of tholeiitic affiliation also become important for further exploration. In the study area, as elaborated above, the altered diabase dyke hosts sulfide mineralization which has been formed by episodic hydrothermal activity [39]. However, the exploration carried out so far is confined only to a limited distance of $5 \mathrm{~km}$ along the trend of this dyke. Detailed mapping, field checks, and sampling [40] has proved the continuity of this dyke for over $20 \mathrm{~km}$. All along this length, though the dyke is intermittently exposed, it shows intense alterations and quartz-carbonate vein activity. This indicates the possibility of the extension of the mineralized dyke, but can only be realized by further detailed exploration. Also, besides base metal potential, there is a likelyhood of uranium concentration in this dyke, as already indicated in a few random sampling (personal communication with Pannerselvum, 2006). This altered 
diabase has been explored by drilling (in 1970s) by State Department of Mines and Geology and the core samples need to be reinvestigated for the possibility of $\mathrm{U}$. It may be important to note here that the altered diabase has been faulted and fractured along with the adjacent granitic rocks, prior to hydrothermal vein ascent, and hence the later hydrothermal fluids could have leached $\mathrm{U}$ from the felsic rocks, i.e. the deformed granite, and precipitated along weak zones.

Some recent studies [41] also show that this area has at least four major fracture zones (confining mainly to granitoids with minor mafic slivers) with strong E-W disposition along which hydrothermal fluid ascent and sulfide indications are strongly manifested which in turn provide a strong possibility of IOCG (iron oxide copper-gold) type mineralization in the studied region.

\section{Conclusions}

The diabase dykes in the northern part of EDC belong to a single stage intrusive activity within the vast sea of granitoids. However, the olivine bearing diabase mostly intruded as poorly differentiated dykes, while the normal diabase as slightly evolved dykes. The $\mathrm{TiO}_{2}, \mathrm{~K}_{2} \mathrm{O}$ and $\mathrm{P}_{2} \mathrm{O}_{5}$ concentrations are suggestive of their origin as continental tholeiitic bodies. They were generated by the partial melting of peridotitic mantle at a depth less than $60 \mathrm{~km}$. The dyke activity in the region represents a post-granite fracturing and mantle melting process around 2.0 Ga. Their (diabase dykes) activity together with the understanding of granite magmatism helps to visualize the crustal evolution processes in the region. It is further inferred that the sulfide mineralization in the altered diabase represents a post-dyke episodic hydrothermal activity. Field, petrographic and geochemical characteristics of the altered (mineralized) diabase, as inferred from the present study, provide further clues for renewed exploration for other strategic metals like Co and $\mathrm{U}$ and perhaps gold. The spatial extent of this dyke also needs to be fully understood in relation with its metal potential.

There is also a need to understand the dyke activity in the studied tract from the point of IOCG type mineralization in a larger context of the structural disturbance, hydrothermal activity, and mobilization/remobilization of metals like $\mathrm{Cu}, \mathrm{Fe}, \mathrm{Co}, \mathrm{Au}, \mathrm{U}$, etc. and their localization in the dykes and their contact zones.

\section{Acknowledgements}

The author is thankful to Dr. K. N. Radhika, Mr. Santosh, Mr. Dayanand and Ms. Pavana for their assistance in preparing the map and geochemical plots.

\section{References}

[1] Swaminath, J., Ramakrishnan, M. and Viswanatha, M.N. (1976) Dharwar Stratigraphic Model and Karnataka Craton Evolution. Records of the Geological Survey of India, 107, 149-175.

[2] Ramakrishnan, M., Viswanatha, M.N. and Swami Nath, J. (1976) Basement-cover Relationships of Peninsular Gneiss with high-Grade Schists and Greenstone Belts of Southern Karnataka. Journal of the Geological Society of India, 17, 97-111. 
[3] Devaraju, T.C. (1995) Mafic Dyke Swarms of Peninsular India. Geological Society of India, Bangalore, 33.

[4] Prabhakar, B.C., Shareef, M., Gireesh, R.V. and Rashmi, B.N. (2008) Fluid Inclusion Study and Hydrothermal Source Characterization of Thinthini Copper Sulfide Deposit, EDC. Indian Mineralogist, 42, 20-32.

[5] MacGregor, A.G. (1931) Clouded Feldspar and Thermal Metamorphism. Mini Magazine, 22, 524-538. https://doi.org/10.1180/minmag.1931.022.133.05

[6] Poldervaart, A. and Gilkey, A.K. (1954) On Clouded Plagioclase. Amer. Miner, 39, 75-91.

[7] Pichamuthu, C.S. (1959) The Significance of Clouded Plagioclase in Basic Dykes of Mysore State, India. Journal of the Geological Society of India, 1, 680-689.

[8] Naidu, P.R.J. (1963) Hypersthene Bearing Rocks of Madras State, India. Presidential Address Given at the South India.

[9] Moorhouse, W.W. (1959) The Study of Rocks in Thin Section. Harper and Row Publishers, New York.

[10] Divakara Rao, V., Hussain, I. and Hussain, S.M. (1970) Petrochemical Studies on a Dyke Near Hyderabad. Bulletin of the National Geophysical Research Institute, 8 , 27-37.

[11] Satyanarayana, K., Naqvi, S.M., Divakara Rao, V. and Hussain, S.M. (1974) Geochemistry of Archean Amphibolites from Karnataka State, Peninsular India. Chemical Geology, 14. 305-315. https://doi.org/10.1016/0009-2541(74)90067-9

[12] Naqvi, S.M., DivakaraRao, V., Satyanarayana, K. and Hussain, S.M. (1972) Petrochemistry of Dolerite Dykes from Shimoga and Chitaldurg Schist Belts. Mysore Geophysics Research Bulletin, 10, 109-123.

[13] MacDonald, G.A. and Katsura, T. (1964) Chemical Composition of Hawaiian Lavas. Journal of Petrology, 5, 82-133. https://doi.org/10.1093/petrology/5.1.82

[14] Armbrustmacher, T.J. (1977) Geochemistry of Precambrian Mafic Dykes, Central Bighorn Mountains, Wyoming, USA. Precambrian Research, 4, 13-38. https://doi.org/10.1016/0301-9268(77)90010-9

[15] Prinz, M. (1964) Geologic Evolution of the Beartooth Mountains. Montana and Wyoming, Part 5. Mafic Dyke Swarms of the Southern Beartooth Mountains. Geological Society of America Bulletin, 75, 1217-1245. https://doi.org/10.1130/0016-7606(1964)75[1217:GEOTBM]2.0.CO;2

[16] McDougall, I. (1964) Differentiation of the Great Lake Dolerite Sheet, Tasmania. Journal of the Geological Society of Australia, 11, 107-132. https://doi.org/10.1080/00167616408728563

[17] Naqvi, S.M. and Hussain, S.M. (1973) Relation between Trace and Major Element Composition of the Chitaldurg Metabasalts, Mysore, India, and the Archean Mantle. Chemical Geology, 11, 17-30.

[18] Cann, J.R. (1971) Major Element Variations in Ocean-Floor Basalts. Philosophical Transactions of the Royal Society of London. Series A, Mathematical and Physical Sciences, 268, 495-505. https://doi.org/10.1098/rsta.1971.0010

[19] Mason, V. (1967) Geochemistry of Basaltic Rocks-Major Elements in Basalts. In: Hess, H.H. and Poldervaart, A., Eds., Basalts-The Poldervaart Treatise on Rocks of Basaltic Composition, Interscience Publishers, New York, 215-269.

[20] Cox, K., MacDonald, R. and Hornung, G. (1967) Geochemical and Petrographic Provinces in the Karoo Basalts of Southern Africa. American Mineralogist, 52, 1451-1474. 
[21] Prinz, M. (1967) Geochemistry of Basaltic Rocks-Minor Elements in Basalts. In: Hess, H.H. and Poldervaart, A., Eds., Basalts-The Poldervaart Treatise on Rocks of Basaltic Composition, Interscience Publishers, New York, 271-323.

[22] Engel, A.E.G., Engel, C.G. and Havers, R.H. (1965) Chemical Characteristics of Oceanic Basalts and the Upper Mantle. Bulletin of the Geological Society of America, 76, 719-734. https://doi.org/10.1130/0016-7606(1965)76[719:CCOOBA]2.0.CO;2

[23] Compston, W., McDougall, I. and Heier, K.S. (1968) Geochemical Composition of the Mesozoic Basaltic Rocks of Antartica, South Africa, South America and Tasmania. Geochimica et Cosmochimica Acta, 32, 129-149. https://doi.org/10.1016/S0016-7037(68)80001-8

[24] Condie, K.C., Barsky, C.K. and Mueller, P.A. (1969) Geochemistry of Precambrian Diabase Dykes from Wyoming. Geochimica et Cosmochimica Acta, 33, 1371-1388. https://doi.org/10.1016/0016-7037(69)90180-X

[25] Jahn, B.-M., Shih, C.-Y. and Rama Murthy, V. (1974) Trace Element Geochemistry of Archean Volcanic Rocks. Geochimica et Cosmochimica Acta, 38, 611-627. https://doi.org/10.1016/0016-7037(74)90045-3

[26] Floyd, P.A. and Winchestor, J.A. (1975) Magma Type and Tectonic Setting Discrimination using Immobile Elements. Earth and Planetary Science Letters, 27, 211-218. https://doi.org/10.1016/0012-821X(75)90031-X

[27] Pearce, T.H., Gorman, B.E. and Birkett (1975) The $\mathrm{TiO}_{2}-\mathrm{K}_{2} \mathrm{O}-\mathrm{P}_{2} \mathrm{O}_{5}$ Diagram: A Method of Discriminating between Oceanic and Non-Oceanic Basalts. Earth and Planetary Science Letters, 24, 419-426. https://doi.org/10.1016/0012-821X(75)90149-1

[28] Fahrig, W.F. and Eade, K.E. (1968) The Chemical Evolution of the Canadian Shield. Canadian Journal of Earth Sciences, 5, 1247-1252. https://doi.org/10.1139/e68-122

[29] Jamieson, B.G. and Clarke, D.B. (1970) Potassium and Associated Elements in Tholeiitic Basalts. Journal of Petrology, 11, 183-204. https://doi.org/10.1093/petrology/11.2.183

[30] Turner, R. and Verhoogen (1962) Igneous and Metamorphic Petrology, McGraw Hill Book, Co., Inc., New York.

[31] Kushiro, I. (1968) Composition of Magmas Formed by Partial Melting of the Earth's Upper Mantle. Journal of Geophysical Research, 73, 619-634. https://doi.org/10.1029/JB073i002p00619

[32] Kuno, H. (1966) Lateral Variation of Basalt Magma across Continental Margins and Island Arcs. Bulletin Volcanologique, 29, 195-222. https://doi.org/10.4095/104478

[33] Yoder, H.S. and Tilley, C.E. (1962) Origin of Basaltic Magma-An Experimental Study of Natural and Synthetic Rock Systems. Journal of Petrology, 3, 342-532. https://doi.org/10.1093/petrology/3.3.342

[34] Prabhakar, B.C., Jayananda, M., Shareef, M. and Kano, T. (2009) Petrology and Geochemitstry of Late Archaean Granitoids in the Northern Part of EDC, Southern India: Implications for Transitional Geodynamic Setting. Geological Society of India, 74, 299-317. https://doi.org/10.1007/s12594-009-0137-2

[35] Ramakrishnan, M. (2009) Precambrian Mafic Magmatism in the Western Dharwar Craton, Southern India. Journal of the Geological Society of India, 73, 101-116. https://doi.org/10.1007/s12594-009-0006-Z

[36] Sarma, D.S., Fletcher, I.R., Rasmussen, B., McNaughton, N.J., Ram Mohan, M. and Groves, D.I. (2011) Archaean Gold Mineralization Synchronous with Late Cratonization of the Western Dharwar Craton, India: 2.52 Ga U-Pb Ages of Hydrothermal 
Monazite and Xenotime in Gold Deposits. Mineralium Deposita, 46, 273-288. https://doi.org/10.1007/s00126-010-0326-3

[37] Barley, M.E. (1992) A Review of Archean Volcanic-Hosted Massive Sulfide and Sulfate Mineralization in Western Australia. Economic Geology, 87, 855-872. https://doi.org/10.2113/gsecongeo.87.3.855

[38] Nielsen, T.F.D. and Brooks, C.K. (1995) Precious Metals in Magmas of East Greenland; Factors Important to the Mineralization in the Skaergaard Intrusion. Economic Geology, 90, 1911-1917. https://doi.org/10.2113/gsecongeo.90.7.1911

[39] Prabhakar, B.C. and Shareef, M. (2015) Shear Zone Controlled Sulfide-Gold Occurrences and Their Fluid Inclusion Characteristics in the Northern Part of Eastern DharwarCraton, Southern India. Journal of the Geological Society of India, 85, 279-288. https://doi.org/10.1007/s12594-015-0216-5

[40] Prabhakar, B.C. (2009) A Report of the Research Project Entitled "Integrated Study on Crustal Evolution and Mineralisation Processes in the Hungund-Yadgir Transect, East Dharwar craton, Southern India. DST, New Delhi.

[41] Prabhakar, B.C. and Shareef, M. (2017) Sulfidic Endowment in Granite-Greenstone Terrain in the Northern Part of EDC: Possibilities of IOCG-Type Mineralizing Episodes. Springer-Verlag, Berlin. (In Press) 